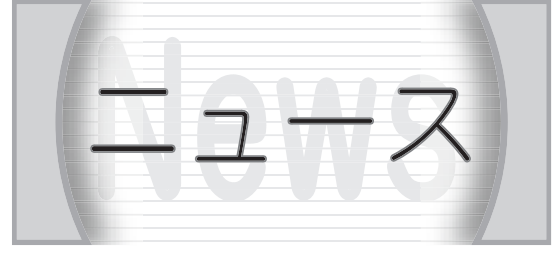

材料・素子

黒リンの高性能トランジスタ 開発

東京大学大学院総合文化研究科の佐 藤洋平大学院生, 上野和紀准教授らは, 東京工業大学フロンティア材料研究所 の笹川崇男准教授らと共同で, “ポス ト・グラフェン”として注目の厚さ原 子数層の黒リンを使った高性能トラン ジスタを開発した。

酸化されやすい黒リンの表面を，電 気化学的なエッチングによって薄く加 工し，空気にさらさずに膜厚を制御す ることに成功した. 試作したトランジ スタのスイッチング動作に必要なバン ドギャップは $1.5 \mathrm{eV}$ と, 従来の厚膜の黒 リントランジスタに比べて約 7 倍に向上 した。これは単原子層の性能に相当す る。トランジスタの性能指標である移 動度を低下させず，バンドギャップを 大きくできたことで，高性能トランジ スタが実現した。黒リンを数原子層の 厚さに薄くし，膜厚を制御すると，バ ンドギャップが変化することは知られ ている。しかし，黒リンは空気中の水 分と反応すると, 移動度などが劣化し てしまう課題があり，これまで動作性 能の高い単原子層トランジス夕は報告 されていない。（日刊工業新聞，2017.3.14）

CNT 採用で塗布型熱電変換材 性能 2 倍

産業技術総合研究所フレキシブルエ レクトロニクス研究センターの末森浩 司主任研究員らは，印刷で形成できる 熱電変換材料を開発した。発電性能は $600 \mu \mathrm{W} / \mathrm{mK}^{2}$ で塗布型の材料としては世 界最高レベルだという。 $200^{\circ} \mathrm{C}$ 以下の排 熱を利用した発電に応用していく.

カーボンナノチューブ (CNT) を絶 縁性の高いポリスチレンと混合した複
合材料を開発した。CNT同士の接点の 絶縁性が上がり，高エネルギーの正孔 が熱電変換に働いたため性能が上がっ たと考えられる。

原料のインクを塗布して乾燥させる だけで作成でき，この手法で作成した 既存材料に比べて 2 倍近い性能だった.

（日刊工業新聞，2017.3.15）

\section{高強度と導電性両立した金属 の複合材}

住友電気工業と住友電工スチールワ イヤーは，電気製品のプラグなど引っ 張ったり差し込んだりする接続部品 や，発電機の電気接点などに用いる， 高い強度と導電性を兼ね備えた金属の 複合線材を開発した。現在はべリリウ ム銅合金が主に用いられているが，べ リリウムが人体に有害なため，代替で きる材料が求められている.

新開発の材料は，弾力のある鋼線に 銅を厚くメッキしたもの. 強度が高く, 力を加えるとバネのようにしなり，導 電性も高い。現在主に使われている心゙ リリウムと銅の合金線材に比べると， 導電性が同等なら強度は約 1.5 倍と高 い. 高強度の鋼線に，導電性の高い銅 を被覆することで，強度と導電性を両 立させた。強度と導電性のバランスは 被覆の厚さで調整可能だが，トータル の性能がベリリウム銅線より高い。導 電性をべリリウム銅線と同等にすると 強度は $50 \%$ 高く，逆に強度を同等にす ると導電率が $50 \%$ 良くなる。

（日経産業新聞，2017.3.16）

\section{テラヘルツ波100倍高感度}

理化学研究所と東京工業大学の共同 チームは, 光波長変換によって, テラ ヘルツ波を従来比 100 倍以上の高感度 で検出する技術を開発した。室温で動 作するテラヘルツ波領域の小型で非破 壊の検査装置の実現につながる.

理研が開発した光波長変換技術を 使ったテラヘルツ波の検出装置を用 い，東工大が開発した共鳴トンネルダ イオードからのテラヘルツ波の放射を 感度よく検出した。トンネルダイオー ドから放射したテラヘルツ波を近赤外
波に波長変換して検出した.

今回用いた実験装置はすべて室温で 動作するため，通常の生活環境で使え るテラヘルツ波領域の非破壊検査装置 の実用化が近づく.

（日刊工業新聞，2017.3.20）

最大容量データ, 光通信で長 距離伝送に成功

NTT未来ねつと研究所やフジクラ は，これまでで最も大容量の情報を光 ファイバで長距離伝送する実験に成功 した。1秒間に 1 ペタビットのデータ を $200 \mathrm{~km}$ 送ることができた。2時間の ハイビジョン映画を 1 秒間に 5,000 本送 る速度に相当する。10年後に必要とさ れる能力を実証したという。

実験にはフジクラが昨年開発した光 の通路（コア）が 32 本通った約 $50 \mathrm{~km}$ のマルチコアと呼ぶ光ファイバを用い た. 直径は $2,430 \mu \mathrm{m}$ で, 光通信で最も 一般的な 1 種類の光に信号を乗せるシ ングルモード技術を使った。

今回はC帯と呼ぶ波長約 $1.5 \mu \mathrm{m}$ 帯域 を使った。仮に同約 $1.6 \mu \mathrm{m}$ のL帯も使 えば，今回の実験結果から推定して毎 秒 1.5 ペタビットの信号を $1,000 \mathrm{~km}$ 以上 送っても正しく伝送できるとみている.

光ファイバを使う情報量は年々増加 し， 10 年後には 1 ペタビットのファイ バが求められる。

（日刊工業新聞/日経産業新聞，2017.3.24)

\section{深紫外 LED 5 倍効率化}

理化学研究所の高効率紫外線 LED 研 究チームの椿健治チームリーダーら は，殺菌用の深紫外発光ダイオードを 従来比約 5 倍効率化することに成功し た. 光取出し効率の高い新型 LED 構造 を作り，現在，殺菌灯として使われて いる水銀ランプの効率に迫る水準を達 成した。殺菌や浄水，医療用の携帯紫 外LEDランプとして実現できる。

加工サファイア基板上に高品質な窒 化アルミニウム層を結晶成長させ，そ の上に $\mathrm{n}$ 型窒化ガリウム層と発光層, 電子ブロック層，透明な $\mathrm{p}$ 型窒化アル ミニウムガリウム層を製膜した。さら に，高い反射特性を持つロジウム電極 
を $\mathrm{p}$ 型電極として形成し， LED構造を 作った。

その結果, 光取出し効果が向上. 素 子の外部に放射される外部量子効果 は, 殺菌用途に最適な $275 \mathrm{~nm}$ 付近の

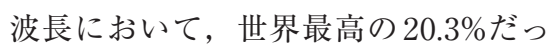
た. 低圧水銀ランプの効率は約 $20 \%$. 高効率な深紫外LED は, 殺菌や浄水, 空気清浄のほか, 医療や農作物の病害 防止に使える. 3D プリンタ等にも応 用可能.

(日刊工業新聞, 2017.3.29)

渦状スピン磁性体発見 トポ ロジカル数制御

東京大学の小澤遼大学院生, 求幸年 教授, 北海道大学の速水賢助教らは, トポロジー(位相幾何学)で取り扱う変 数 (トポロジカル数)を持つ, スピンの 向きが渦状の微小な新しい磁気構造体 「磁気スキルミオン」を発見した。

研究チームは, 磁性金属中において, トポロジカル数が 2 の新しい磁気スキ ルミオン結晶が現れ, 磁場に応じてト ポロジカル数が多段階に変化する現象 を理論的に突き止めた。磁場中で現れ るトポロジカル数が 1 の従来型とは起 源の異なる新しい磁気スキルミオン結 晶で, これが磁場のない状態でも安定 に存在することがわかった。

トポロジカル数を多段スイッチング できるようになれば，微小磁場を使っ た多值メモリーの動作などが可能にな ると見达まれる。（日刊工業新閆，2017.4.4)

\section{レーザ発振・高速変調動作} ナノワイヤで実証

NTTは, 光通信波長帯のナノワイヤ で初めて, レーザ発振打よび高速変調 動作を実証した。シリコンチップ上に ナノワイヤを土台とした多機能なナノ レーザを積んだ小型の光集積デバイス が実現できる。

光の波長より細い半導体ナノワイヤ を人工的な周期構造であるシリコンの フォトニック結晶上に配置し, 光を空 間的に閉じ込める光ナノ共振器を形成 した。これによってレーザを連続発振 させ，このレーザを使ってナノワイヤ として初めて $10 \mathrm{Gbps}$ の高速変調動作
に成功した，将来は，プロセッサー チップの中に高密度な光ネットワーク を導入する手段として用いることが期 待される。

(日刊工業新聞, 2017.4.7)

スピン制御 新原理実証 量子 集積チップの光操作実現

横浜国立大学の小坂英男教授らは, 量子コンピュータや量子通信の高速化 につながる光スピン制御の新原理を実 証した。ダイヤモンド中の窒素空孔中 心 (NV中心) に存在する単一の電子ス ピンを, レーザ光で自在かつ正確に操 作する新原理であり，これを実験で確 認した. 数 $\mu \mathrm{W}$ の小さい光パワーを使 いながら, 従来比より約 100 倍高速の $1 \mathrm{~ns}$ で, 従来より約 3 倍高精度に単一 スピンを操作することに成功した。

量子情報処理に必要な, 書込み, ゲート制御, 読出しの全操作が微弱な レーザ光で行えるようになり，量子集 積チップの光操作を実現する. 量子コ ンピュータや量子通信の高速化を開く 成果となる。今後は，これらの技術を 使って, 量子テレポーテーション転写 や量子もつれ測定などの実証を進める.

(日刊工業新聞，2017.4.11)

世界初「カーボンナノベルト」 合成に成功

名古屋大学の伊丹健一郎教授, 瀬川 泰知特任准教授, ポビー・ギョム博士 研究員らは, 筒状 (ベルト状) の炭素分 子「カーボンナノベルト (CNB)」の合 成に世界で初めて成功した。

伊丹教授らは，歪みのない環状分子 を合成した上で，これを筒状構造に変 換する手法を考案. 安価な石油成分で あるパラキシレンを炭素原料に使い， カーボンナノベルトを合成した．合成し たカーボンナノベルトは直径約 $0.8 \mathrm{~nm}$. 各種分析により, 同じ筒状の炭素物質 であるカーボンナノチューブ (CNT) に似た構造や性質を持ち, CNT の部分 構造であることが示された。

従来のCNT製法では，大きさや構造 の異なる混合物しか得られないため, CNTの応用を阻んでいた.カーボンナ ノベルトを使えば，特定の機能を持つ
単一構造のCNTを作り分けられるた め, $\mathrm{CNT}$ の本格的な応用を切り開くと 期待される。

単一構造のCNTが作れれば, 軽くて 折り曲げ可能なディスプレイや省電力 の超集積中央演算処理装置 (CPU) の開 発，太陽電池の効率化などに寄与する. (日刊工業新聞, 2017.4.14)

安価に「スピン液体」を作製/ 次世代メモリーへの応用に道

東北大学のコスマス・プラシデス教 授と高林康裕助教と英リバプール大学 のマシュー・ロゼインスキー教授ら は, 次世代メモリーへの応用が期待さ れる新素材を開発した。炭素と水素か らなる分子が集合した結晶で, 電子の 磁石 (スピン) の向きが摇れ動く「スピ ン液体」と呼ぶ性質を示す。信号「0」, $\lceil 1 」 の$ 中間状態を設定できるようにな り, 従来に比べてはるかに大量のデー 夕を蓄積できる可能性があるという.

開発したのはベンゼン環が 3 個つな がったフェナントレンが整然と並んだ 結晶. 各分子がスピンを 1 個ずつ持ち, 近接するスピン同士は三角形を組む。 一般の磁性材料は磁場中で冷却すると スピンの向きがそろって動かなくなる. 新素材は室温から測定した零下約 $271{ }^{\circ} \mathrm{C}$ までスピンが摇れ動いた。さら に同約 $201{ }^{\circ} \mathrm{C}$ 以下では三角形で隣同士 のスピンが反平行に向こうとして摇れ 動くスピン液体であることがわかった.

同様の素材はこれまで 5 種類見つ かっているが, 応用に至っていない。 新素材は豊富な元素で作れ, メモリー や量子コンピュータへの応用が期待さ れている。

（日刊工業新聞/日経産業新聞，2017.4.25)

物質表面のナノ構造アルミを 変化させることで思い通りの 色彩を表現

理化学研究所の田中拓男主任研究員 やレニルクマール・ムダチャディ国際 特別研究員らは，ナノスケールの“座 布団”を物質表面に作り，思い通りの 色にみせる技術を開発した。アルミニ ウムの薄膜を樹脂に塗り，数百ナノ 
メートルサイズのアルミの構造体を並 べることで，赤から紫までの可視光全 域の色を作り出せた。

ナノ構造体を大量に集積し, 光の吸 収などの光学特性を人工的に操作した 物質は「メタマテリアル」と呼ばれ注目 されている。1種類の金属の構造を変 えるだけで多くの色を作りだす研究は 珍しい.

研究グループは，開発した技術を利 用し，理研のロゴマークを作製した。 元の画像とほぼ同様の青と緑で構成さ れるロゴを再現できた。 さらに赤と緑 と青のそれぞれのナノ構造体を空間的 に近い場所に置き，見た目の色が混ざ るようにしたところ，黒く見えること を確認した。

開発した薄膜は厚さ $200 \mathrm{~nm}$ と薄く, ペンキに比べ $1 / 500$ の重量で済む. 光 学機器の内壁や, 重さが問題となる大 型望遠鏡内の黒色塗装などへの応用が 期待できる。

(日刊工業新聞，2017.4.27)

\section{機器・システム}

光子 1 個ごと見える顕微鏡

産業技術総合研究所の福田大治氏ら は，光子 1 個を見ることのできる「光 子顕微鏡」を開発した。光ファイバで 極めて弱い光を集め, 超電導光センサ で波長や個数を数える. 可視光に加え 赤外光, 紫外光も計測可能である.

超電導光センサは，100 $\mathrm{mK}$ に冷やさ れており，光子が当たると一時的に超 電導状態が壊れる。この瞬間の電気抵 抗の変化から光子のエネルギーを見積 もり，光子の波長を識別する. 波長 $200 \mathrm{~nm} \sim 2000 \mathrm{~nm}$ の光子を計測可能. 光ファイバの先端に集光レンズをつ け, 試料表面上を走査して画像を撮る。 実験では，1画素あたり平均 20 個程度 の光子を検出して画像を作成できた. 光強度に換算すると $0.16 \mathrm{fW}$ に相当し, 世界初の成果となった。

光子 1 個 1 個を観測できれば，同時 に複数の物質を分けて計量可能. 細胞 の自家蛍光観察や化学物質の蛍光分析 など，微弱な光の観察に応用する。今
後は，超電導光センサの検出部を複数 並べて，動画撮影の実現を目指す。 (日刊工業新聞, 2017.4.6 ; 日経産業新聞, 2017.4.13)

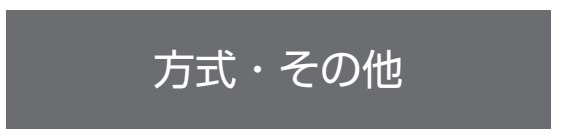

地デジによる水蒸気量の測定 手法開発

情報通信研究機構は, 地上デジタル 放送の電波を使った水蒸気量の推定手 法を開発した.ピコ秒の精度で電波の 伝搬遅延を計测できるようにし，ソフ トウェア無線技術を用いて, 水蒸気量 を測れる小型で安価なリアルタイム測 定装置を開発した.ゲリラ豪雨などの 局所的な気象現象の予測精度の向上が 見达める.

電波は, 大気中の水蒸気量によって 伝わる速度が変わるため, その変化量 を精密に測定することで水蒸気量が推 定可能. 情通機構電磁波研究所の川村 誠治主任研究員らの研究チームは, 地 デジ放送波から電波の伝搬遅延を求め る手法を考案した。地デジ放送波を受 信するだけで計測でき，新たな送信機 などは不要. 分解能が高く, 1〜 30秒 ごとに水蒸気量を観測できる．最も水 蒸気の多い地表付近を水平方向に観測 するため，既存の鉛直方向の観測手法 を補える. 雨の元になる水蒸気の量は, 気象予報にとって重要な情報だが, レーダーなどでは観測できないため, 広い範囲にわたって効果的に観測する 手法が限られていた。

(日経産業新聞，2017.3.13）

\section{Al 活用の映像解析技術}

日立製作所は AI 活用し，性別や服 の色, 所持品など 100 項目以上の人物 の特徴をリアルタイムに判別すること で探したい人物を即座に発見し，追跡 可能な技術を開発した。同技術により， 大規模施設や街区などの防犯カメラ映 像から, 特徴に合致する人物の発見が 可能になる.

同社はこれまでに数百台のカメラを 用いた次世代のネットワーク型大規模 監視システムを開発してきた。今回の

技術では，カメラに映った人物の 12 種 類 100 項目以上の外見に関する特徴と, 10 項目の動作に関する特徴をリアル夕 イムに判別する。従来の技術に比べ, 複数の項目を同時に判別する演算方法 を使用. 必要な計算量を約 $1 / 40$ に削減 し, 高速な人物発見が可能になった.

さらに，AIによる画像解析結果を日 立独自の高速ベクトル検索データベー スに記録し，数万人の画像が記録され た中から 1 秒以内で同一人物の映像を 抽出する。顔画像を解析した場合と比 較し, 同一人物の発見精度を 3 倍以上 に改善した。

（電波新聞，2017.3.28）

数学理論で結晶構造解析

山形大の富安亮子准教授と高エネル ギー加速器研究機構 (KEK) の神山崇 教授は, ビッグデータ処理の一種であ る「グラフ解析」を使って新物質の結晶 構造を解く手法を開発した。代数学の グラフ解析を結晶構造解析の格子決定 に初めて導入した手法で, 企業や研究 機関で広く使われる測定装置の実験 デー夕を元に, 結晶格子を従来よりも 短時間で $100 \%$ 近い確率で突き止める ことができる.

企業や試験研究機関にある数千台の 粉末結晶材料の X 線回折測定装置の データは，これまで多くの時間をかけ て解析されていたが, 数学の理論を使 えば特有の問題を解決できるとして, 新たなソフトを開発した。

新ソフトは, CONOGRAPH (コノグ ラフ）として KEKが管理するサーバか ら配布している。従来ソフトが1時間 前後かけて結晶格子決定の成功率が 40 〜 60\%だったのに対し，新ソフトは 5 〜 10 分程度で $80 \%$ の成功率だった。こ れには極端に困難なデー夕も含んでい るため, 事実上 $100 \%$ 近い成功率であ り，新材料開発の加速につながる成果 という。

(日経産業新聞, 2017.4.21)

〔執筆担当〕

澤 和秀 委員 (東 芝)

澤谷郁子 委員 $(\mathrm{NHK})$

新保豪平 委員 $(\mathrm{NEC})$

野中敬介 委員 (KDDI総合研究所) 